\title{
Influence of Mineral Composition to Rock Strength on UCG Process
}

\author{
Zulfahmi $^{1}$, Ildrem Syafri ${ }^{2}$, Abdurrokhim ${ }^{3}$, Ridho K. Wattimena ${ }^{4}$ \\ ${ }^{1} \mathrm{R} \&$ D Center for Mineral and Coal Technology, Jl. Jend. Sudirman No. 623 Bandung, Indonesia \\ ${ }^{2,3}$ Faculty of Geology Engineering, Padjadjaran University, Jl. Raya Bandung-Sumedang Km. 21 Jatinangor, Indonesia \\ ${ }^{4}$ Faculty of Mining and Petroleum Engineering, Bandung Institute of Technology, Jl. Ganesha No.10 Bandung 40132, Indonesia
}

\begin{abstract}
Underground coal gasification (UCG) process needs the stability of cavities around the coal seam for continuation of its the process. The stability of the cavities depends on the rocks strength adjacent of the coal seam, especially the rocks on the roof cavities. UCG process will lead to changes in rock mineralogy structure due to high thermal load around $700-900{ }^{\circ} \mathrm{C}$ or above and the existence of the thermal load also resulted in changes of the rock strength. To know these changes has been investigated experimentally in the laboratory the behavior of claystone samples from originating from the proposed of UCG pilot plant in MusiBanyuasin district, South Sumatera-Indonesia. Laboratory tests have been done with $X$-Ray diffraction (XRD), X-Ray Fluorescence (XRF) and geomechanics test to claystone samples before and after thermal treatment. The thermal load has been done by giving the variation of temperature at $30-$ $1100^{\circ} \mathrm{C}$. This is assumed as the condition of temperature variation at the space of UCG gasifier. In this paper also discussed the consequences of the changes of mineral structures and chemistry element to rock strength and conditions cavity after the UCG process.
\end{abstract}

Keywords: claystone, rock strength, thermal load, UCG

\section{Introduction}

Currently Indonesia is preparing alternative energy to fill the gap of oil and gas supplies, one of them is the implementation of underground coal gasification (UCG) technologies. This technology is one of the most promising to the exploitation of coal deposit which are not available by conventional methods. The UCG can be directly converted into a syngas under the in-situ condition without the need to remove overburden, so that the environmental aspect and safety is better than the conventional mine. Power plants or chemical industries could be processed from the syngas and could be converted to further chemical syntheses [5], [12]. Although the UCG technology has the potential to be developed in Indonesia by applying the clean coal technologies, cheap and safe for the coal reserves that are technically unmineable and uneconomic to mine by mean conventional mining methods, however, there are potential risks to watch out for when rocks adjacent of coal seam for UCG process is not able to hold the thermal loads and stresses in the roof rock.

The two risks must be watched out are the gaseous product from UCG may pose a potential threat to the environment due to organic contaminants that produced during the UCG process migrating through the crack of the weak rock that surrounding the coal seam and ground subsidence [11]. Underground cavities will be created due to the coal combustion process that allows the roof rock above the cavity to failure. The roof rocks failure will affect the rocks strata above it till to the surface, so infrastructure at the surface will be disrupted and the hydrological condition on the top of cavities will also be damaged [7], [13]. The temperature of gasifier or reactor where the UCG process takes place will be increased till high temperature around $700-900{ }^{\circ} \mathrm{C}$ or above and will affected mineralogies structures of the rocks in the surrounding of the process [1]. Alteration of the structure of mineralogy and chemistry of the rocks due to the increasing temperature will also be changing the rock strength [4], [15].

This paper discusses changes in mineralogical structure and chemical composition of claystone samples through laboratory studies and these changes are correlated with changes of the rock strength, other geomechanics characteristics and consequences of such changes to the cavities conditions post gasification. The thermal load with temperature variations of $30^{\circ} \mathrm{C}-1100^{\circ} \mathrm{C}$ charged to the claystone samples in this laboratory test is assumed to be a temperature variation in the space of the UCG gasifier / reactor.

\section{Materials and Methods}

The object of research is claystone samples originated from cap rocks or adjacent rocks of the coal seam that the target of UCG at MusiBanyuasin, South Sumatera, Indonesia. To keep the samples from failure, cracks or fissures before tested, the samples dried at room temperature as two weeks and also dried by oven at the temperature $100^{\circ} \mathrm{C}$ for $1-2$ hours to remove remaining water content. Furthermore, to investigate experimentally the effect of temperature on the alterations of mineralogical, chemical structures, and geomechanical characteristics of claystone samples, several testing such as X-Ray Fluorescence (XRF), X-Ray Diffraction (XRD), physical and mechanical properties (triaxial test) has been done before and after thermal load treatment

The thermal load treatment process is done by gradual heating to the desired maximum temperature and then cooling process is done in the furnace. To prevent drastic heat changes in the rock samples, the heating rate is maintained at $10 \mathrm{C} / \mathrm{min}$ until it reaches the desired temperature. At the maximum temperature desired, the samples remain in the furnace for 1 hour and then cooled in the furnace until the space temperature closed at room 


\section{International Journal of Science and Research (IJSR) \\ ISSN (Online): 2319-7064 \\ Index Copernicus Value (2015): 78.96 | Impact Factor (2015): 6.391}

temperature. The variation of temperatures is $30^{\circ} \mathrm{C}$ (room temperature), $100^{\circ} \mathrm{C}, 200^{\circ} \mathrm{C}, 300^{\circ} \mathrm{C}, 400^{\circ} \mathrm{C}, 500^{\circ} \mathrm{C}, 600^{\circ} \mathrm{C}$, $700^{\circ} \mathrm{C}, 800^{\circ} \mathrm{C}, 900^{\circ} \mathrm{C}, 1000^{\circ} \mathrm{C}$ and $1100^{\circ} \mathrm{C}$

Differ to samples for XRD and XRF tests, the physical and mechanical properties test required samples with a diameter $5,5-6,3 \mathrm{~cm}$. The minimum length of samples is two times the diameter of rocks samples and the preparation of its samples by dry methods. Preparation of the test samples has been done by core drilling that taken directly by using a core barrel and in the laboratory subsequently prepared again to cut the cores according to the required dimensions. Laboratory analysis for mineral and chemical compositions of rock samples were done after geomechanical testing due the rock samples ex-the tests can still be used for mineral and chemical composition test. Chemical and mineral composition tests were performed using XRD and XRF methods.

\section{Result and Discussion}

\subsection{XRD and XRF studies before thermal treatment}

The test results of several claystone samples before given thermal load treatment indicated that the mineral content of the rocks was dominated by quartz, kaolinite, illite and siderite (Type I, Kaolinite) and quartz, pyrite, monmorillonite, orthoclase and anorthite (type II, Non Kaolinite). Figure 1 shows the XRD test results of type I and Type II respectively.
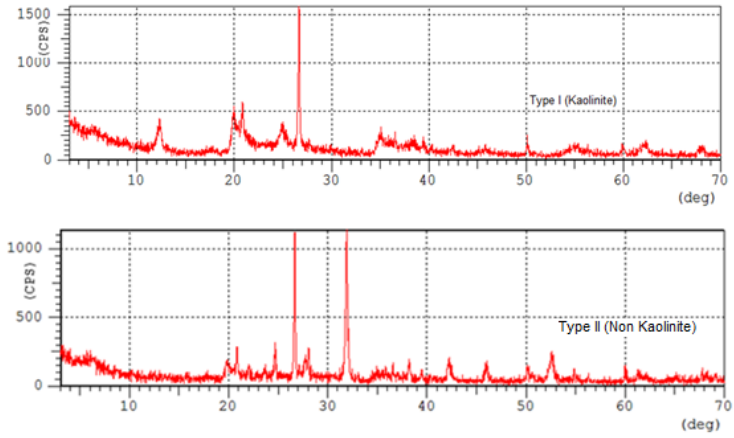

Figure 1: XRD Analysis (Type I and Type II) before thermal treatment

The composition compounds of claystone comprise $\mathrm{SiO}_{2}$, $\mathrm{CaO}, \mathrm{MgO}, \mathrm{Fe}_{2} \mathrm{O}_{3}, \mathrm{Al}_{2} \mathrm{O}_{3}$ and several others. While based on the results of the tests with XRF method, showed that the content of elements in the sample generally consists of elements $\mathrm{Si}, \mathrm{Fe}, \mathrm{Al}, \mathrm{Cl}, \mathrm{K}, \mathrm{Ca}, \mathrm{Ti}, \mathrm{S}, \mathrm{Zr}, \mathrm{Mn}, \mathrm{Sr}$ and metal elements in small content relatively (Figure 2).

\subsection{XRD and XRF studies after thermal treatment}

The test results after being given thermal treatment showed the mineral content of rock samples both type I and type II dominated by quartz and cristobalite, but in type II still found the albite minerals. Figure 3 shows the XRD test results for type I and II of the claystone after thermal load treatment respectively.

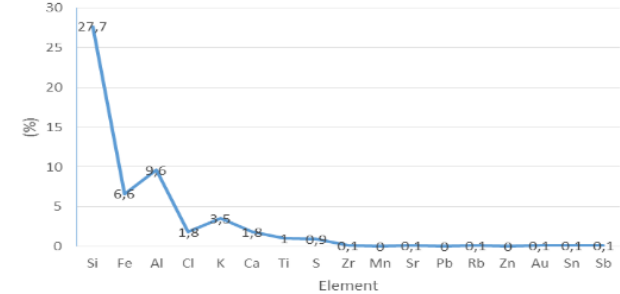

Figure 2: XRF Analysis of Claystone before thermal treatment
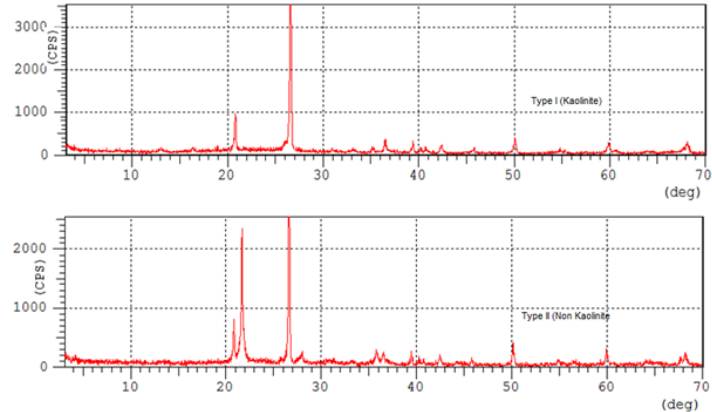

Figure 3: XRD Analysis (Type I and Type II) after thermal treatment $\left(1100^{\circ} \mathrm{C}\right)$

In Table 1 it is shown that there is a change in the percentage of chemical composition of each mineral before and after heating.

Table 1:Comparison of chemical analysis before and after thermal treatment

\begin{tabular}{|c|c|c|c|c|}
\hline \multirow{3}{*}{$\begin{array}{c}\text { Constituent } \\
(\%)\end{array}$} & \multicolumn{4}{|c|}{ Claystone } \\
\cline { 2 - 5 } & \multicolumn{2}{|c|}{ Type I } & \multicolumn{2}{c|}{ Type II } \\
\cline { 2 - 5 } & Before & After & Before & After \\
$\left(30^{\circ} \mathrm{C}\right)$ & $\left(1100^{\circ} \mathrm{C}\right)$ & $\left(30^{\circ} \mathrm{C}\right)$ & $\left(1100^{\circ} \mathrm{C}\right)$ \\
\hline $\mathrm{SiO} 2$ & 51,12 & 66,63 & 60,81 & 71,002 \\
$\mathrm{Al} 2 \mathrm{O} 3$ & 38,43 & 29,32 & 20,84 & 16,96 \\
$\mathrm{Fe} 2 \mathrm{O} 3$ & 1,01 & 0,35 & 2,98 & 3,71 \\
$\mathrm{TiO} 2$ & 0,01 & 0,01 & 0,42 & 0,27 \\
$\mathrm{~K} 2 \mathrm{O}$ & 0,92 & 0,62 & 0,52 & 0,40 \\
$\mathrm{CaO}$ & 5,12 & 2,84 & 5,35 & 4,39 \\
$\mathrm{MnO}$ & 0,02 & 0,003 & 0,01 & 0,004 \\
$\mathrm{MgO}$ & 0,42 & 0,19 & 0,02 & 0,017 \\
$\mathrm{Na} 2 \mathrm{O}$ & 0,05 & 0,01 & 2,59 & 1,15 \\
$\mathrm{P} 2 \mathrm{O} 5$ & 0,053 & 0,01 & 0,053 & 0,021 \\
$\mathrm{SO} 3$ & 0,014 & 0,001 & 0,074 & 0,035 \\
$\mathrm{Cr} 2 \mathrm{O} 3$ & 0,01 & 0,001 & 0,01 & 0,019 \\
$\mathrm{CuO}$ & 0,004 & 0,001 & 0,004 & 0,005 \\
$\mathrm{NiO}$ & 0,005 & 0,002 & 0,005 & 0,005 \\
$\mathrm{PbO}$ & 0,002 & 0,001 & 0,002 & 0,001 \\
$\mathrm{Rb} 2 \mathrm{O}$ & 0,012 & 0,001 & 0,012 & 0,012 \\
$\mathrm{SrO}$ & 0,008 & 0,002 & 0,008 & 0,007 \\
$\mathrm{ZnO}$ & 0,012 & 0,001 & 0,014 & 0,010 \\
$\mathrm{ZrO} 2$ & 0,018 & 0,001 & 0,018 & 0,016 \\
$\mathrm{LOI}$ & 2,762 & 0,01 & 6,26 & 1,955 \\
\hline
\end{tabular}

From these data it can be seen that the percentage of $\mathrm{SiO} 2$ is increasing, some of the other minerals are decreasing and some are increasing, that is indicating that there has been changes of mineral structures inside the rock when given the thermal load. Figure 4 shows the change of chemical elements in claystone after given the variation of thermal treatment. 


\section{International Journal of Science and Research (IJSR) \\ ISSN (Online): 2319-7064}

Index Copernicus Value (2015): 78.96 | Impact Factor (2015): 6.391

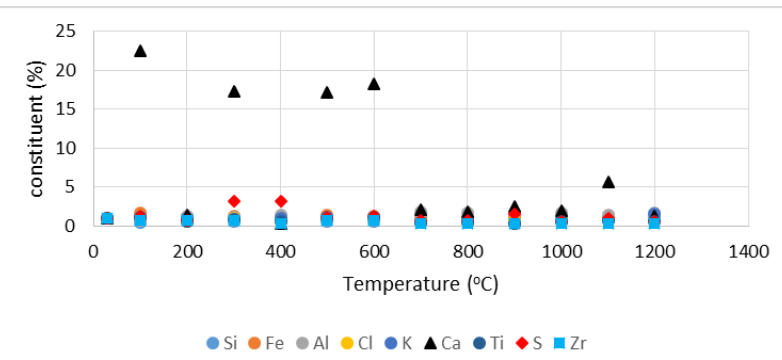

Figure 4: Changes of constituent (\%) in the thermal load variation

\subsection{Geomechanics studies}

To evaluate rock strength conditions of claystone samples before and after given thermal treatment, several geomechanics tests have been done such as physical properties (density and porosity) and mechanical properties (triaxial) test. Based on test results, the density of claystone samples both the type I and type II shows tend to decrease when the increasing of the thermal load treatment (Figure 5). While, the porosity of the samples both type I and type II has increased when the increasing of the thermal load treatment (Figure 6).

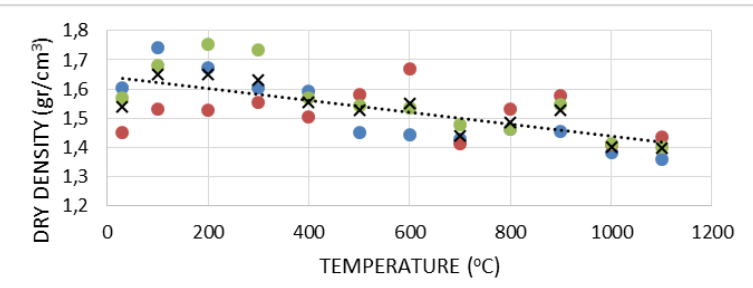

Figure 5: Density decrease rate versus temperature variation

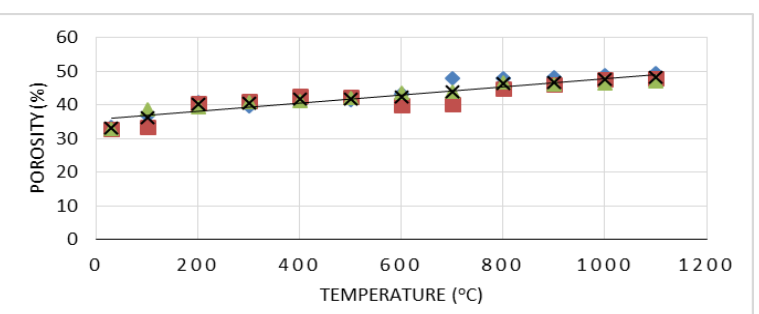

Figure 6: Total porosity increase rate versus temperature variation

From triaxial tests, it is known that there is a significant difference between the strength of the claystone type I and type II. The strength of type I claystone are increased when the increase of the thermal load that's being given to the samples, but the strength of the type II claystone even decrease such as shows on the changes of the failure stress value from several variations of confining pressure at Figure 7. Figure 8 shows the condition of the average of elastic modulus for both types of the claystone. The elastic modulus is the ability to maintain the conditions of rocks in a state of elastic [6].

The value of elastic modulus of the rocks generally tends decrease when given the increasing of thermal load treatment [3], [2], [8]-[10]. However, base on the triaxial test result of the study, the elastic modulus value of the type I claystone samples were tend increase when given the increasing of thermal load treatment but the type II even were decrease such as shown on Figure 8. This suggests that an increase or decrease of the elastic modulus values at any thermal load is strongly influenced by the conditions of the microstructure (chemical and mineral composition) of the claystone samples.

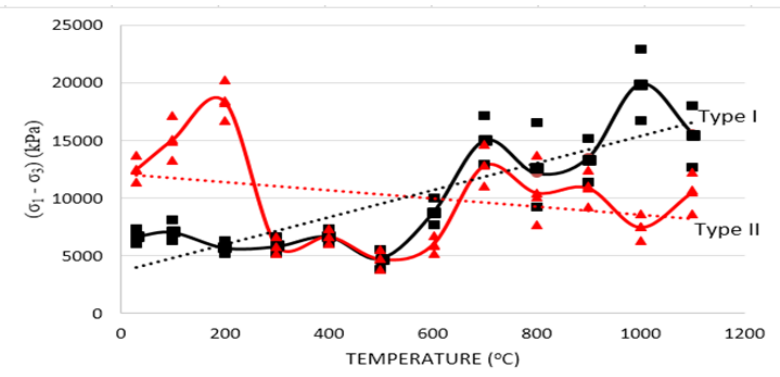

Figure 7: Failure stress of type I and II claystone versus temperature variation

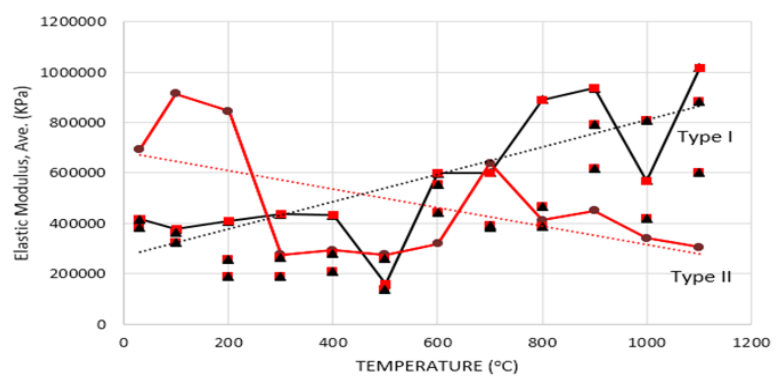

Figure 8: Elastic Modulus of type I and II claystone versus temperature variation

With the increased thermal load received by rocks generally show an increasing trend of axial strain for some rock samples such as sandstone, limestone and coal [10]. However, the axial strain of the claystone samples in the study, shows the difference tends between the sample type I and II. Based on the result of a triaxial test with confining pressure variations of $50 \mathrm{kPa}, 100 \mathrm{kPa}$ and $200 \mathrm{kPa}$ for claystones sample type I even was steady or did not show increasing of axial strain values when given being the increasing of the thermal load whereas the type II of claystone were increased.

Based on the test result of the study, showed that for type I claystone, changes of thermal load do not really affect to the rate of deformation, while for type II claystone, the greater the thermal load received of the rock samples then the greater the axial deformation or strain occurring. Figure 9 shows the variation of axial strain to the increased thermal load as a form of change of axial deformation.

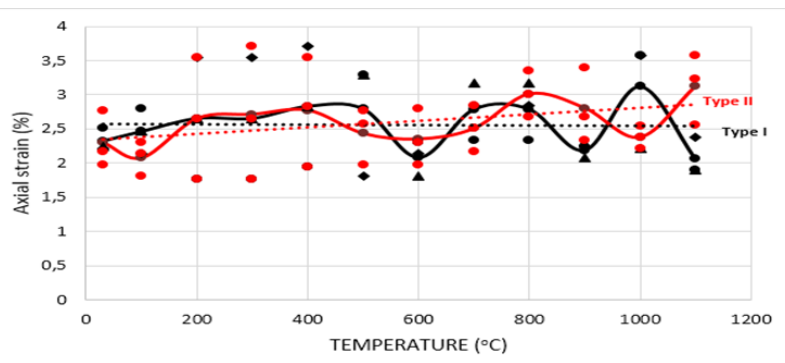

Figure 9: Axial strain of type I and II claystone versus temperature variation

\section{Volume 6 Issue 6, June 2017 www.ijsr.net}




\section{International Journal of Science and Research (IJSR) \\ ISSN (Online): 2319-7064}

Index Copernicus Value (2015): 78.96 | Impact Factor (2015): 6.391

\subsection{Claystone behavior on thermal load variations}

The mineral contents in the claystone can affect the strength of rock and when the rocks are given the thermal load, then the rocks strength can changes become hard or weak. The compounds of oxides when exposed to the high thermal load can be crystallized so the rocks become stronger, but if found the minerals that have swelling properties such as monmorilloniteand then the porosity of rocks becomes large causing weakening of the rock strength. The compounds of alkali oxides such as feldspar and mica which function as flux can decrease of the melting point of the combustion process [14]. In claystone type I which have kaolinite minerals, the water discharge process occurs at temperatures above $100{ }^{\circ} \mathrm{C}$ and gradually decomposed at a temperature of $450^{\circ} \mathrm{C}$ by removing the hydroxyl group (-OH) and transformed into meta-kaolin. However, if there is no significant temperature rise, then can also happen on a back reaction that changes the structures into kaolinite back. At higher temperatures, the meta-kaolin will react to form crystalline compounds which will ultimately form the free silica (cristobalite) and mullite. In claystone type II, the minerals such as montmorillonite will remove the hydroxyl group $(\mathrm{OH})$ into water at a temperature of $650 \mathrm{oC}$ and the rocks that originally swelling then shrinking.

The studies that have been conducted on claystone samples show fairly consistent variations when given the variation of thermal load. The claystone samples of the type I show the trend of rock strength increased when the thermal load is increasing, but for type II claystone samples showed a tendency to weaken when the thermal load increases. This difference condition is inseparable from the condition of the samples tested included the mineral content of the rocks constituent.

\section{Conclusion}

A set of laboratory test to investigate the correlation of mineral composition to rock strength of claystone exposed to variety of thermal loads from $30^{\circ} \mathrm{C}$ to $1100^{\circ} \mathrm{C}$ has been carried out. The variation of thermal load assumed as a condition of the UCG gasifier/reactor.

XRD test results showed that the structure of mineralogy of the rocks changes when given the variation of thermal load. The significant increase of the constituent minerals in claystone samples after being given a thermal load until the temperature reaches $1100 \mathrm{oC}$ is quartz minerals, while other minerals generally decrease, except for hematite (Fe2O3) which increases in the claystone type II.

Geomechanical test results investigated before and after being given the thermal load for parameters of density, porosity, rock strength, elastic modulus and axial strain show different behavior. The density of claystone decreases with increasing thermal load received by the rock and vice versa the porosity of claystone increases with increasing thermal load received by rocks. To determine changes in the mechanical properties of claystone before and after given thermal load treatment has been done triaxial tested.The rock strength (failure stress) and elastic modulus increase when the increasing of the thermal load for the claystone type I and conversely decreased strength when the thermal load increases.

Increased thermal load does not cause an increase or decrease in deformation Increased thermal load does not cause an increase or decrease in the load deformation at claystone samples of type I, whereas the increase in the thermal load on the type II claystone cause increased axial deformation or strain of the rock.

\section{Acknowledgements}

Author greatly appreciates Mr. Suhendar for his support to my research and the laboratory staff at the rock mechanics and chemistry and physics laboratory for their support on samples testing. The research described in this paper was financially supported by R \& D Center for Mineral and Coal Technology.

\section{References}

[1] Burton, E., Friedmann, J., and Upadhye, R. "Best Practices in underground coal gasification," Report, Lawrence Livermore National Laboratory, W-7405Eng-48, 2007.

[2] Dengina N.I., Kazak V.N. and Pristash V.V. "Changes in rocks at high temperatures", A. A. Skochinskii Inst. of Hydrodynamics, Lyubertsy. No. 5, pp. 96-103, 1993.

[3] Hettema M.H., De Pater C.J., Wolf K-H.A.A. "High temperature properties of roof rock of coal rock characterization”, ISRM Symposium: EUROCK 1992, pp. 93-98), 1992.

[4] Ma ZG, Mao XB, Li YS, Chen ZQ, Zhu P, "The lab study of influence of temperature to coal mechanics characteritics", Ground Press Strata Control, 22(3): 46 $-8,2005$.

[5] Perkins, G. "Mathematical modelling of Underground Coal Gasification", University of New South Wales, Ph.D. theses, 257 pp., 2005.

[6] Rai, M.A., Kramadibrata, S. and Wattimena, R.K. "TA 3111-Mekanika batuan", Catatankuliah, Laboratoriumgeomekanikadanperalatantambang, InstitutTeknologi Bandung, 2011.

[7] Sury M, White M, Kirton J, Carr P and Woodbridge R. "Review of Environmental Issues of Underground Coal Gasification", Report No. COAL R272 DTI/Pub URN 04/1880, 2004. University of Liège Belgium: 126, 2004.

[8] Su H.J, Jing H W., Mao X B, Zhao H H., Yin Q. and Wang C. (2015), "Size effect of sandstone after high temperature under uniaxial compression", J. Cent. South Univ. (2015) 22: 1901-1908, 2015

[9] Tian H., Kempka T., Schlüter R., Feinendegen M. and Ziegler M. " Infl. of high temperature on rock mass surr. in situ coal conv. Sites", 10th Int. Sym. on Env. Geotech. andSust. Dev., 2009.

[10] Tian, H. "Development of a Thermo-Mechanical Model for Rocks Exposed to High Temperatures during Underground Coal Gasification", Ph.D. Thesis, RWTH Aachen University, Aachen, Germany, 2013.

[11] Torres, V.N., Atkins. A.S. and Singh, R.N. "Assessment of an environmental sustainability index for the underground coal gasification process by using

\section{Volume 6 Issue 6, June 2017 www.ijsr.net}




\section{International Journal of Science and Research (IJSR) \\ ISSN (Online): 2319-7064}

Index Copernicus Value (2015): 78.96 | Impact Factor (2015): 6.391

numerical analysis", Coal Operator's Conference, Research Online, University of Wollongong, 2014.

[12] Wachowicz, J., Janoszek, T., Iwaszenko, S. "Model tests of the coal gasification process", Archives of Mining Sciences, Vol. 55, No 2, p. 249-262, 2010.

[13] Walter K. "Fire in the hole: Underground coal gasification may provide a secure energy supply and reduce greenhouse gas emissions. Lawrence Livermore National Laboratory", Science, and Tech. Rev., p. 12$18,2007$.

[14] Worrall, W.E. “ Clays and Ceramic Raw Materials”, Elsevier Applied Science Publisher, 1986.

[15] Zhang L., Mao X. and Lu A. "Experimental study on the mechanical properties of rocks at high temperature", Science in China Series E: Tech. Sciences, vol. 52, no 3, pp. 641-646, 2009.

\section{Author Profile}

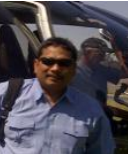

Zulfahmi, received the B. Sc.degree from Sriwijaya University and M. Sc. degree from Bandung Institute of Technology, Indonesia. He is currently a researcher in R \& D Center for Mineral \& Coal Technology, Ministry of Eenergy and Mineral Resources.

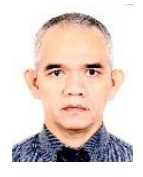

Ildrem Sjafri, Professor of petrography, Padjadjaran University who interst as well on the geopressure study in sedimentary rock. He received his bachelor degree from Padjadjaran University, master and doctor degree from Marie-Curie University in France.

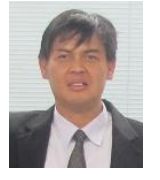

Abdurrokhim, he is Lector in Faculty of Geology, Padjadjaran University. He received the B. Sc. Degree from Padjadjaran University, master degree from Bandung Institute of Technology, Indonesia and Ph.D. degree from Chiba University Japan.

Ridho K. Wattimena, Professor of rock mechanics, Bandung Institute of Technology. He received the B. Sc. and Master degree from Bandung Institure of Technology, Indonesia and $\mathrm{Ph}$. D. degree from University of Queensland. 